Available online at website :

http:/ / e-journal.adpgmiindonesia.com/index.php/jmie

JMIE: Journal of Madrasah Ibtidaiyah Education, 5(2), 2021, 200-213

\title{
THE DEVELOPMENT OF STUDENT WORKSHEET BASED ON HIGHER ORDER THINKING SKILLS IN IMPROVING MATHEMATICS LEARNING OUTCOMES
}

\author{
Retno Intan Kuswari, Choiruddin \\ Departement of Teacher Education at Madrasah Ibtidaiyah \\ Postgraduate Program, State Islamic Institute of Tulungagung \\ Email: intanretno900@gmail.com,choiruddinmail@gmail.com
}

Submit: 16 Februari 2021, Revisi: 10 Oktober 2021, Approve: 8 November 2021

\begin{abstract}
The use of instruction tools that does not know the extent to which students' understanding causes the instruction process to be less than optimal. This study aims to find out the development process, feasibility, and the influence of using student worksheet based on higher order thinking skills in improving Mathematics learning outcomes at MIN 3 Tulungagung and SDI Qurrota A'yun Ngunut Tulungagung by the model of Borg, and Gall. The results show that: (1) The development of HOTS-based worksheets begins with preparing instruction materials in the 2013 Curriculum, makes examples of HOTS questions, making questions individual, and group practice questions and then make competency test questions at the end of the chapter. (2) The worksheets based on HOTS are suitable for use in improving Mathematics learning outcomes. This can be seen from the results of due diligence by media and material experts. (3) There is an influence of using HOTS-based worksheets as indicated by the significant difference in learning outcomes between the experimental class that does instruction using HOTS-based worksheets and the control class that does instruction without HOTS-based worksheets. This is based on the data from the t-test results in which sig-2 0.040 $<0.050$ is obtained.
\end{abstract}

Keywords: high order thinking, learning outcomes, mathematics.

Pengutipan: Retno Intan Kuswari \& Choiruddin. (2021). The Development of Student Worksheet based on Higher Order Thinking Skills in Improving Mathematics Learning Outcomes. JMIE: Journal of Madrasah Ibtidaiyah Education, 5(2), 2021, 200-213. jmie.v5i2.333.

Permalink/DOI: http://dx.doi.org/10.32934/jmie.v5i2.333 


\section{INTRODUCTION}

Education has an important role and is quite influential in providing quality and highly competitive human resources. The time used in education of someone is often used as a benchmark in shaping one's competitiveness. The young generation has an important role in finding out the fate of this nation in the future. The education received by children at this time, especially the formal education received in schools will find out the quality of the nation in the future (S. Nasution, 2016). Education held in Indonesia refers to the national education goals listed in the Republic of Indonesia Law No. 20 of 2003 concerning the National Education System in article 3 (Gloria, 2016). The educational objectives are related to the results of instruction activities which are not only seen from a cognitive perspective, but also include affective and psychomotor aspects (Al-Tabany, 2017).

In the mid-20th century, to be precise before the 1950, teaching was still defined as a process of providing guidance and increasing the abilities of students, where everything that was done during the teaching process was still teacher-centered (Suyono \& Hariyanto, 2011). But then, instruction in the current era is targeted at instruction that can stimulate students to become active, creative, critical and fun learners so that meaningful instruction will be created (Hidayati, 2017). The instruction in Indonesia is currently using the 2013 curriculum using a scientific approach. The scientific approach is thought to improve students 'instruction achievement and can improve students' higher order thinking skills. However, the obstacle that has been obtained so far is the difficulty of training students' higher-order thinking skills. Therefore, as educators, they must have a breakthrough so that students are trained to think at higher levels.

One of the lessons that can train students' higher order thinking skills is learning mathematics. Mathematics is a universal science that is useful for human life and underlies the development of modern science and technology, and has an important role in various disciplines to improve and develop human thinking. According to Lestari, learning mathematics not only requires students to simply understand the material being studied at that time, but also learn with understanding and actively build new knowledge (K. E. Lestari \& Yudhanegara, 2017).

High Order Thinking Skills is the ability to relate, manipulate, and change knowledge, and experience that already has critically, and creatively in making decisions to solve problems in new situations. These high order thinking skills include problem-solving skills, creative thinking skills, critical thinking, argumentation skills, and decision-making abilities. High order thinking skills in other theory said that include critical, logical, reflective, metacognitive, and creative thinking (Miedijensky et al., 2021).

The main purpose of high order thinking skills is how to improve students' thinking skills at a higher level, especially those related to the ability to think critically in receiving various types of information, think creatively in solving a problem using the knowledge they have and 
make decisions in situations, and the complex situation (Bahri et al., 2021). Higher order thinking skills will not be achieved by themselves without the efforts and means of support. The ministry of education law Number 16 of 2007 concerning Academic Qualification Standards and Teacher Competencies states 2 competencies that educators must have in the pedagogical dimension are being able to develop indicators and assessment instruments and being able to develop components of instruction design.

One of the printed teaching materials used in schools is student worksheets. student worksheet is one of the teaching materials that plays an important role in providing assignments that are relevant to the material being taught (Santoso et al., 2021). Previous research by Utari, Hobri, Oktavianingtyas in 2017, with the title Development of Mathematics-Oriented Student Worksheets to Foster Higher Order Thinking Ability. Tends to be the same as the examples that have been given by the teacher. However, when students are given questions that are slightly different from the examples given, students will find it difficult to solve these problems (Utari et al., 2017).

The previous study was conducted by Purwaningrum at SDN 4 Puyoh with the research subjects being fifth grade students, and showed that the average mathematical problem solving ability test results of students using learning aided discovery learning were under the Maximum Completeness Criteria. That criteria in the research class for mathematics is 75 . The study also shows that students' mathematical problem solving skills using visual aid-assisted discovery learning do not reach 75\% classical completeness (Purwaningrum, 2016).

The results of research related to PISA show that there are still low-ability students when testing mathematical literacy skills in several types of content and the same context. This is caused by many factors, including variations in the questions and material chosen (Yulistianti \& Megawati, 2019). Lambertus also argues that students have weaknesses when asked to analyze questions, determine strategies and settlement processes, as well as re-examine the results obtained. They usually prioritize the results obtained rather than the techniques used when solving problems. whereas analysis, and evaluation of the learning process is an important skill that they must develop in high order thinking (Lambertus et al., 2020).

The material that they have not mastered optimally includes difference of the definitions of various set operations. They also have not been able to solve set problems that are associated with problems in daily life. This has an impact on student grades that are not completed. Most of the students' scores are below the minimum standard (Hawa, 2014). The low ability of students to solve problems needs to be corrected by providing practice questions that are different from the examples given by the teacher. One of them is by using the Higher Order Thinking Skill question which is a complex problem and one of them is open ended. One way to help students so that they can think more critically and creatively is to use student 
worksheets which contain questions that train high-order thinking or what is called Higher Order Thinking Skills .

Regarding the educational problems that have been described, researchers will conduct research at one of the State Islamic Primary Schools in Tulungagung Regency, namely MIN 3 Tulungagung and at SDI Qurrota A'yun Ngunut Tulungagung. Both schools have implemented the 2013 curriculum by applying higher-order thinking instruction. The research location also has good potential and conditions as well as adequate facilities such as the availability of adequate classrooms, internet access, libraries and others that support the implementation of this research.

\section{METHODS}

Research and development or research and development was a research method used to produce certain products (Syaodih, 2008). Borg and Gall used the term Research and Development which is defined as a process or method used to validate and develop products. These developments can take the form of updating existing products to make them more practical, influenceive, and efficient, or actually creating new products that were not there before (Syaodih, 2007). This research will use 7 stages from Borg and Gall's research and development steps, namely research and data collection, planning, development of initial product formats, product validation, revision of product validation results, small-scale field trials, and revision of product results, field trials.

The development procedure is an explanation of the prefind outd development model. The steps taken in the Borg and Gall development procedure include:

\section{Trial Design}

This activity begins with collecting data and testing the feasibility of the product by means of validation by several experts. Test the feasibility of the product by giving a questionnaire to the validator to assess the level of validity, as well as the practicality of the product being developed, as well as due diligence on the target product use.

2. Subject Trial

The trial subjects consisted of experts in the field of media, experts in the field of materials, as well as product use targets (Grade IV students at MIN 3 Tulungagung and SDI Qurrota A'yun).

3. Types of Data

The type of data used is quantitative data and qualitative data. Quantitative data is data in the form of numbers (Suharyadi \& K., 2003), while qualitative data is data related to categorization, characteristics in the form of questions and statements in the form of words (Riduwan, 2015). Quantitative data were obtained from preliminary research in the form of 
observations and data from small group tests and field tests. Qualitative data were obtained from various expert / validator reviews.

a. Data Collection Instruments

This study uses several data collection instruments to find out how far the success of the product developed is, including observation, questionnaires, and interviews.

b. Data Analysis Techniques

The data analysis technique applied in this research and development is quantitative data analysis which begins with a feasibility analysis. The research data on the feasibility of developing HOTS-based worksheets in mathematics learning will be analyzed descriptively. The formula for processing percentage descriptive data is as follows (Andri Aka et al., 2018):

$$
V=\frac{T S e}{T S h} \times 100 \%
$$

Note:

$V \quad$ : Validity

$T S e$ : empiric score

TSh : maximal score

Validation is done to try out products that have been revised in instruction practices. Validation focuses on product applicability, namely whether the product can be used or not.

Table 1. The Feasibility Presentation of Product

\begin{tabular}{ccc}
\hline No & Criteria & Feasibility Level \\
\hline 1 & $81,00 \%-100,00 \%$ & Very feasibility \\
2 & $61,00 \%-80,00 \%$ & Feasibility \\
3 & $41,00 \%-60,00 \%$ & Less Feasibility \\
4 & $21,00 \%-40,00 \%$ & Not Feasibility \\
5 & $00,00 \%-20,00 \%$ & Very not Feasibility \\
\hline
\end{tabular}

After going through this feasibility analysis stage, the researcher then continued testing the influenceiveness analysis consisting of validity tests, reliability tests, then the researchers also went through the homogeneity, normality test stages, and finally the $t$ test, to find out the influence of using the module. 


\section{RESULTS AND DISCUSSION}

\section{Higher Order Thinking Skills}

Rosnawati explained that high-order thinking skills can occur when someone associates newly received information. That information already stored in their memory, then connects and / or rearranges and develops that information so that a goal or a solution to a situation that is difficult to solve is achieved (Rosnawati, 2013). Therefore,Fanani categorized HOTS as follows: (1) critical thinking and logical thinking, (2) reflective thinking, (3) metacognitive thinking, and (4) creative thinking. How to evaluate students' HOTS can be done by measuring it in several ways, namely (1) choosing (multiple choices, matching, and items), (2) generalizing (short answers, essays), and (3) giving reasons (Fanani, 2018).

The efforts to improve students' ability to be able to solve problems require skills to find, analyze, create, reflect, and argue or what is often referred to as higher order thinking skills. Honing these skills can be done through objective or subjective questions that require reasoning to answer which are known as HOTS (Higher Order Thinking Skills) questions. Higher order thinking skills require abilities ranging from remembering, referring, applying to analyzing, evaluating, or creating (Awaliyah, 2018).

Sudarmin said that HOTS can be realized through integration in the instruction process and assessment. Developing HOTS items must follow the established rules, both regarding the writing of the item in general and the rules based on the level of thinking of students. HOTS questions can be designed using operational verbs in accordance with the cognitive realm of analyzing, evaluating, and creating (Sudarmin, 2012).

In the technical guide for integrated thematic instruction, the ministry of education and culture explains that teachers must train students in the form of higher order thinking skills or higher order thinking skills, with the aim of increasing the ability of students to think critically to answer more complex questions. or solve a more complicated problem (A. D. Lestari \& Siregar, 2019).

HOTS-based worksheets can be said as question sheets or student work that can train them to think more critically and creatively in solving complex problems. In this student worksheet is also equipped with supporting materials that will make it easier for students to achieve the desired instruction goals.

In developing HOTS-based worksheets, student worksheet acts as a instruction tool that can support the teaching and instruction process in the classroom. HOTS-based questions can train students in critical and creative thinking, so that students can solve more difficult problems.

\section{Mathematics Learning}


Mathematics includes aspects of numbers, algebra, geometry and measurement as well as statistics and probability. In line with this opinion, James and James in their mathematics dictionary, said that mathematics is the science of logic about form, arrangement, quantity, and concepts that are related to one another in large numbers which are divided into three fields, namely algebra, analysis. and geometry (Clapham \& Nicholson, 2009).

Meanwhile, according to Soedjadi, namely having an abstract objective object, relying on an agreement, and a deductive mindset. From the definition above, we can illustrate that mathematics has its own language, namely the language of symbols which contains concepts that are mutually sustainable and have uses in various fields.

Peaget said that elementary school students between the ages of 6 or 7 , to 12 or 13 are in a concrete operational phase. The ability that appears in this phase is the ability in the thought process to operate logical rules, even though it is still tied to concrete objects (Fardah et al., 2014). Learning mathematics in early childhood greatly affects the whole process of learning mathematics in the following years. If the basic concepts laid down are not strong or the child gets a bad impression on his first introduction to mathematics, then the next stage will have difficulty (Yeni, 2015).

At this age they still need concrete objects in understanding something, for example concepts, to understand a mathematical concept in its entirety, they need tools or teaching aids to facilitate and accelerate their understanding. So that it can be used as an initial foundation in the mathematics teaching and instruction process. It is hoped that students do not perceive mathematics as a scourge but rather a fun and interesting lesson to learn.

Bruner revealed that in learning mathematics, students must find out for themselves the various knowledge they need (Fardah et al., 2014). The ultimate goal of learning mathematics in $\mathrm{SD}$ is for students to be skilled in using various mathematical concepts in everyday life. The following is a instruction explanation that emphasizes mathematical concepts :

1. Instilling Basic Concepts, namely instruction to instill basic concepts is a bridge that must be able to connect students' concrete cognitive abilities with new abstract mathematical concepts. So that props are needed that will help students' thinking patterns ability.

2. Understanding the concept, is a continuation of concept instilling. Instruction concept understanding is carried out at different meetings.

3. Skills development, continued from concept instilling and concept understanding. This stage aims to make students more skilled in using various mathematical concepts. From the concept above, it is intended that students are more skilled in understanding concepts and applying them to everyday life. So that students do not have difficulty solving daily problems related to the concepts that have been learned. 


\section{Development of Student Worksheet Based on Higher Order Thinking Skills}

This research and development resulted in a product in the form of Higher Order Thinking Skills -based worksheets which were developed with reference to the Borg and Gall development model. The development of this student worksheet begins with conducting research and collecting data in the field. Research and data collection are needed in order to find out the location of the research, material and analyze the needs used as the basis for the preparation of the product being developed. The researcher chose the research location AT MIN 3 Tulungagung and SDI Qurrota A'yun Ngunut Tulungagung on the grounds that the school had already implemented the 2013 curriculum by applying high-level thinking instruction. In addition, the school also has complete facilities and infrastructure that can support this research activity.

Next, the researcher find outs the core competencies, basic competencies, and teaching materials of the subjects used. The material used in this study is the subject of Mathematics for grade IV semester two, which is focused on Chapter 3, namely Angle Measurement. The material was chosen because it was in accordance with the time of the research conducted by the researcher. Meanwhile, the basic competencies in accordance with the teaching material presented are translated into indicators of competency achievement which are then used as references in making questions in competency tests or practice questions on the Higher Order Thinking Skills -based worksheets.

After finding out the school and material to be used, the next step is to conduct a needs analysis. Based on the results of observations and interviews that researchers conducted, educators at MIN 3 Tulungagung and SDI Qurrota A'yun Ngunut Tulungagung have implemented modules or textbooks in their instruction process. It's just that the modules used are still limited and only used to explain the subject matter. The process to find out the extent to which students' understanding is still limited to verbal and sometimes question and answer activities given practice questions contained in the module.

The next step is to compile a Instruction Implementation Plan (RPP) for one-time faceto-face, create an attractive HOTS Student Worksheet adapted to the characteristics of elementary / MI students, compile a research instrument in the form of a material expert validation questionnaire, a media expert validation questionnaire, as well as the post test instrument.

a. Lesson plan

This Instruction Implementation Plan (RPP) is used for one face-to-face $(2 \times 35$ minutes). The preparation of the RPP is based on the Mathematics book used by teachers from the National Education Office but is slightly modified so that it is more interesting and easy for teachers to understand and can be implemented in the classroom. The Instruction Implementation Plan (RPP) in this study will be presented as attached. 
b. Making worksheets based on HOTS

The making of HOTS-based worksheets begins with preparing instruction materials in accordance with the Core Competencies and Basic Competencies listed in the 2013 curriculum. Then the researcher makes examples of HOTS questions that match the material that has been presented, making individual and group practice questions to strengthen understanding of students and finally making competency test questions to measure the extent to which students understand the instruction material that has been presented in one chapter. The next step is to create a cover design. The cover design is made attractive and adapted to the teaching material. Then the HOTS-based worksheets are given variations in the form of interesting pictures and words of motivation to learn to make students excited and attract their curiosity.

c. Preparation of Research Instruments

Researchers used four research instruments to obtain data related to the feasibility and the influence of using the developed worksheets. The material expert validation questionnaire instrument was used to find out the suitability of the material in the instruction media with the material in the textbook. The media expert validation questionnaire was used to find out the feasibility of the media being developed, both in terms of appearance, content and ability to assist the instruction process. Post test questions will be tested on material experts to find out the suitability of the questions with indicators and basic competencies of teaching materials. The data from the instrument is then analyzed and corrected (if necessary), before being used to collect data in the field.

The next stage is the development of the initial product with HOTS-based worksheets product components that will be developed including covers, said pengatar, table of contents, instruction materials, individual and group practice questions, competency test questions. The development of Higher Order Thinking Skills based worksheets was validated by media and material experts before being tested in the field. The results of the validation of all experts on several aspects presented indicate that the development of Higher Order Thinking Skills -based worksheets is feasible to be tested at MIN 3 Tulungagung and SDI Qurrota A'yun Ngunut Tulungagung. This is evidenced by the validation of media experts and material experts with a questionnaire instrument. 


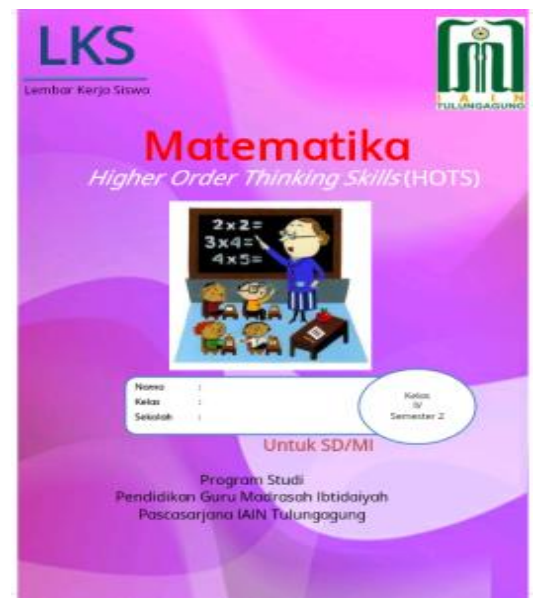

Figure 1. The worksheets based on HOTS

\section{Feasibility Test for Using Higher Order Thinking Skills Based Worksheets}

The feasibility test of HOTS-based worksheets is carried out through four stages of validation starting from the validation stage of media experts, validation of material experts, validation of post-test questions and finally, trials of a small group of students consisting of 18 students. Validation of instructional media experts, validation of instruction material experts, and validation of post tests were carried out on two experts in this field. Furthermore, researchers conducted field trials conducted on 4A grade students at SDI Qurrota A'yun Ngunut Tulungagung (experimental class) and 4A grade at MIN 3 Tulungagung (as a control class).

Based on the test results from the first media expert, the linguistic aspect got a percentage of $87.5 \%$ and the second media expert got a percentage of $83.33 \%$. For the presentation aspect, the first media expert gave a percentage of $83.33 \%$, as well as the second media expert who gave a percentage of $83.33 \%$. The aspect of the influence of the use of media gets a percentage of $90 \%$ from the first media experts and $90 \%$ from the second media experts. The overall viewability assessment aspect received a percentage of $87.5 \%$ of the first media experts and $83.33 \%$ of the second media experts. Based on these data, the product developed meets the valid category so that it is suitable for use in the instruction process with revisions in several parts.

The results of material validation in instruction media developed from material experts on the aspect of relevance got a percentage of $85 \%$ from the first material expert and a percentage of $90 \%$ from the second material expert. The aspect of using language gets a percentage of $81.25 \%$ from the first material expert and a percentage of $93.75 \%$ from the second material expert. Whereas in the aspect of ability, it got a percentage of $100 \%$ from the first material expert and a percentage of $83.33 \%$ from the second material expert. This data shows that the material is included in the valid category, so it can be concluded that the material 
Retno Intan Kuswari \& Choiruddin

contained in the instruction media developed is in accordance with the teaching material with the applicable 2013 curriculum.

\section{The Influence of Using Student Worksheet based on Higher Order Thinking Skills}

The results of data analysis from the post-test scores that were previously carried out by the normality test met the criteria for a normal distribution with a significance value of 0.397 (experimental class) and a significance value of 0.411 (control class) so that the post-test value analysis could be carried out using t-test analysis (independent sample t-test) which resulted in a significant $0.040<0.050$, so it can be seen that there is a significant difference between the control class and the experimental class. Based on previous research reviewed by researchers, instruction that applies HOTS-based worksheets is very helpful for students in training critical and creative thinking. The following is a table of the test results:

Table 2. Output of Independent Sample T-test

Independent Samples Test

\begin{tabular}{|c|c|c|c|c|c|c|c|c|c|c|}
\hline & & & $\begin{array}{l}\text { ene's } \\
\text { for } \\
\text { ality } \\
\text { f } \\
\text { inces }\end{array}$ & & & t-test $\mathrm{f}$ & Equalit & of Means & & \\
\hline & & $\mathrm{F}$ & Sig. & $\mathrm{T}$ & Df & $\begin{array}{l}\text { Sig. } \\
(2- \\
\text { tailed) }\end{array}$ & $\begin{array}{l}\text { Mea } \\
\mathrm{n} \\
\text { Diffe } \\
\text { rence }\end{array}$ & $\begin{array}{l}\text { Std. Error } \\
\text { Differenc } \\
\text { e }\end{array}$ & $\begin{array}{l}95 \% \\
\text { Conf } \\
\text { Inter } \\
\text { the } \\
\text { Diffe }\end{array}$ & $\begin{array}{l}\text { lence } \\
\text { li of } \\
\text { ence }\end{array}$ \\
\hline & & & & & & & & & $\begin{array}{l}\text { Lowe } \\
\mathrm{r}\end{array}$ & Upper \\
\hline nilai & $\begin{array}{l}\text { variances } \\
\text { assumed }\end{array}$ & $\begin{array}{l}.09 \\
5\end{array}$ & .759 & 2.120 & 39 & .040 & 5.850 & 2.759 & .269 & $\begin{array}{l}11.43 \\
1\end{array}$ \\
\hline & $\begin{array}{l}\text { variances } \\
\text { not } \\
\text { assumed }\end{array}$ & & & 2.193 & $\begin{array}{l}38.97 \\
8\end{array}$ & .034 & 5.850 & 2.668 & .453 & $\begin{array}{l}11.24 \\
7\end{array}$ \\
\hline
\end{tabular}

According to the results of research conducted by Utari, Hobri, and Oktavianingtyas, shows that HOTS-based worksheets help students understand the material by thinking more critically and creatively (Utari et al., 2017). Based on previous research and theories that have been reviewed by researchers, it can be concluded that instruction using HOTS-based worksheets can help the instruction process, train students to think critically and creatively. So it can be concluded that there is a significant influence between the experimental class teaching using Higher Order Thinking Skills based worksheets and the control class teaching without 
using Higher Order Thinking Skills based worksheets on the mathematics learning outcomes of grade IV students.

\section{CONCLUSION}

The development of HOTS-based worksheets begins with preparing instruction materials in accordance with the Core Competencies and Basic Competencies listed in the 2013 Curriculum. Furthermore, the researcher makes examples of HOTS questions that match the material that has been presented, makes individual and group practice questions and then make competency test questions at the end of the chapter. HOTS-based worksheets are suitable for use in improving mathematics learning outcomes. This can be seen from the results of due diligence by media and material experts. Furthermore, through the final test, it is known that there is an influence of using HOTS-based worksheets. This is indicated by the significant difference in learning outcomes between the experimental class that does instruction using HOTS-based worksheets and the control class who does instruction without HOTS-based worksheets. This is based on the data from the t-test results which obtained sig-2 $0.040<0.050$.

\section{REFERENCES}

Al-Tabany, T. I. B. (2017). Designing innovative, progressive, and contextual learning models (Mendesain model pembelajaran inovatif, progresif, dan kontekstual). In Prenadamedia Group.

Andri Aka, K., Akbar, S., \& Sahertian, J. (2018). Development of V alidation Instrument for Interactive Multimedia Learning Implementation Plan. https:/ / doi.org/10.2991/ ecpe-18.2018.25

Awaliyah, S. (2018). Penyusunan Soal Higher Order Thinking Skills Bagi Guru Pendidikan Pancasila dan Kewarganegaraan dan Ilmu Pengetahuan Sosial Sekolah Menengah Pertama. Jurnal Praksis Dan Dedikasi Sosial. https://doi.org/10.17977/um032v0i0p48-55

Bahri, A., Jamaluddin, A. B., Muharni, A., Fikri, M. J. N., \& Arifuddin, M. (2021). The Need of Science Learning to Empower High Order Thinking Skills in 21st Century. Journal of Physics: Conference Series, 1899(1). https://doi.org/10.1088/1742-6596/1899/1/012144

Clapham, C., \& Nicholson, J. (2009). The Concise Oxford Dictionary of Mathematics. In The Concise Oxford Dictionary of Mathematics. https://doi.org/10.1093/acref/9780199235940.001.0001

Fanani, M. Z. (2018). Strategi Pengembangan Soal Higher Order Thinking Skill (HOTS) dalam Kurikulum 2013. Edudeena, 2(1).

Fardah, D. K., Ariyadi, W., Jusmanidar, J., Saefudin, A. A., Sutarto, H., Eka, lestari karunia, Ridwan, Y. M., Fahrurrozi, Syukrul, H., Heruman, Ahmad, S., Atiaturrahmaniah, Marsa, I. D. S., Musabihatul, K., Luthfiyah, N., Euis, I., Muchlas, S., Suparji, Asto, B. G. P., ... 
Satria, K. (2014). Taksonomi Berpikir. JPM IAIN Antasari, 01(1).

Gloria. (2016). Perubahan Paradigma Perpustakaan Menghadapi Tantangan Era Digital. Ugm.Ac.Id.

Hawa, A. M. (2014). Analisis Kemampuan Siswa Menyelesaikan Soal PISA Bertipe PISA. Seminar Nasional Evaluasi Pendidikan Tahun 2014.

Hidayati, A. U. (2017). Melatih Keterampilan Berpikir Tingkat Tinggi dalam Pembelajaran Matematika pada Siswa Sekolah Dasar. Pendidikan Dan Pebelajaran Dasar, 4(20).

Lambertus, A., Keene, K., \& Coats, H. (2020). From the Classroom: Wanted: your number sense! Teaching Children Mathematics, 16(5). https://doi.org/10.5951/tcm.16.5.0260

Lestari, A. D., \& Siregar, H. P. (2019). ANALISIS BUTIR SOAL MATEMATIKA BUATAN GURU SMP NEGERI 1 MEMPURA. Pi: Mathematics Education Journal, 2(1). https://doi.org/10.21067/pmej.v2i1.2837

Lestari, K. E., \& Yudhanegara, M. R. (2017). Penelitian Pendidikan Matematika. In PT.Refika Aditama.

Miedijensky, S., Sasson, I., \& Yehuda, I. (2021). Teachers' Learning Communities for Developing High Order Thinking Skills-A Case Study of a School Pedagogical Change. Interchange, 52(4). https://doi.org/10.1007/s10780-021-09423-7

Purwaningrum, J. P. (2016). MENGEMBANGKAN KEMAMPUAN BERPIKIR KREATIF MATEMATIS MELALUI DISCOVERY LEARNING BERBASIS SCIENTIFIC APPROACH. REFLEKSI EDUKATIKA, 6(2). https:/ /doi.org/10.24176/re.v6i2.613

Riduwan. (2015). Metode dan Teknik Menyusun Skrisi dan Tesis. In Bandung: Alfabeta.

Rosnawati, R. (2013). Kemampuan Penalaran Matematis Siswa SMP Indonesia pada TIMSS 2011. Prosiding Seminar Nasional Penelitian, Pendidikan Dan Penerapan MIPA.

S. Nasution. (2016). Sosiologi Pendidikan. Sosiologi Pendidikan.

Santoso, A. M., Primandiri, P. R., Zubaidah, S., \& Amin, M. (2021). The development of students' worksheets using project based learning (PjBL) in improving higher order thinking skills (HOTs) and time management skills of students. Journal of Physics: Conference Series, 1806(1). https://doi.org/10.1088/1742-6596/1806/1/012173

Sudarmin, S. (2012). Meningkatkan kemampuan berpikir tingkat tinggi mahasiswa melalui pembelajaran kimia terintegrasi kemampuan generik sains. Varia Pendidikan, 24(1).

Suharyadi, \& K., P. S. (2003). Statistika Deskriptif. Statistika Untuk Ekonomi Dan Kenangan Modern.

Suyono \& Hariyanto. (2011). Belajar dan pembelajaran Teori dan konsep Dasar. In Bandung: PT Remaja Rosdakarya.

Syaodih, N. (2007). Metode Penelitian Pendidikan. In Bandung: Pustaka Setia. 
Syaodih, N. (2008). Metode Penelitian Penelitian dan Pengembangan. Jakarta: Kencana., 1985.

Utari, T., Hobri, \& Oktavianingtyas, E. (2017). Pengembangan Lembar Kerja Siswa (LKS) Matematika Berorientasi Scientific Approach untuk Menumbuhkan Kemampuan Higher Order Thinking (HOT) Pokok Bahasan Persamaan Lingkaran pada Siswa SMA Kelas XI. Kadikma, 8(2).

Yeni, E. M. (2015). Kesulitan Belajar Matematika Di Sekolah Dasar. JUPENDAS: Jurnal Pendidikan Dasar, 2(2).

Yulistianti, H. D., \& Megawati, E. (2019). Analisis Instrumen Tes Higher Order Thinking. Jurnal Pendidikan Matematika, 13(1). 